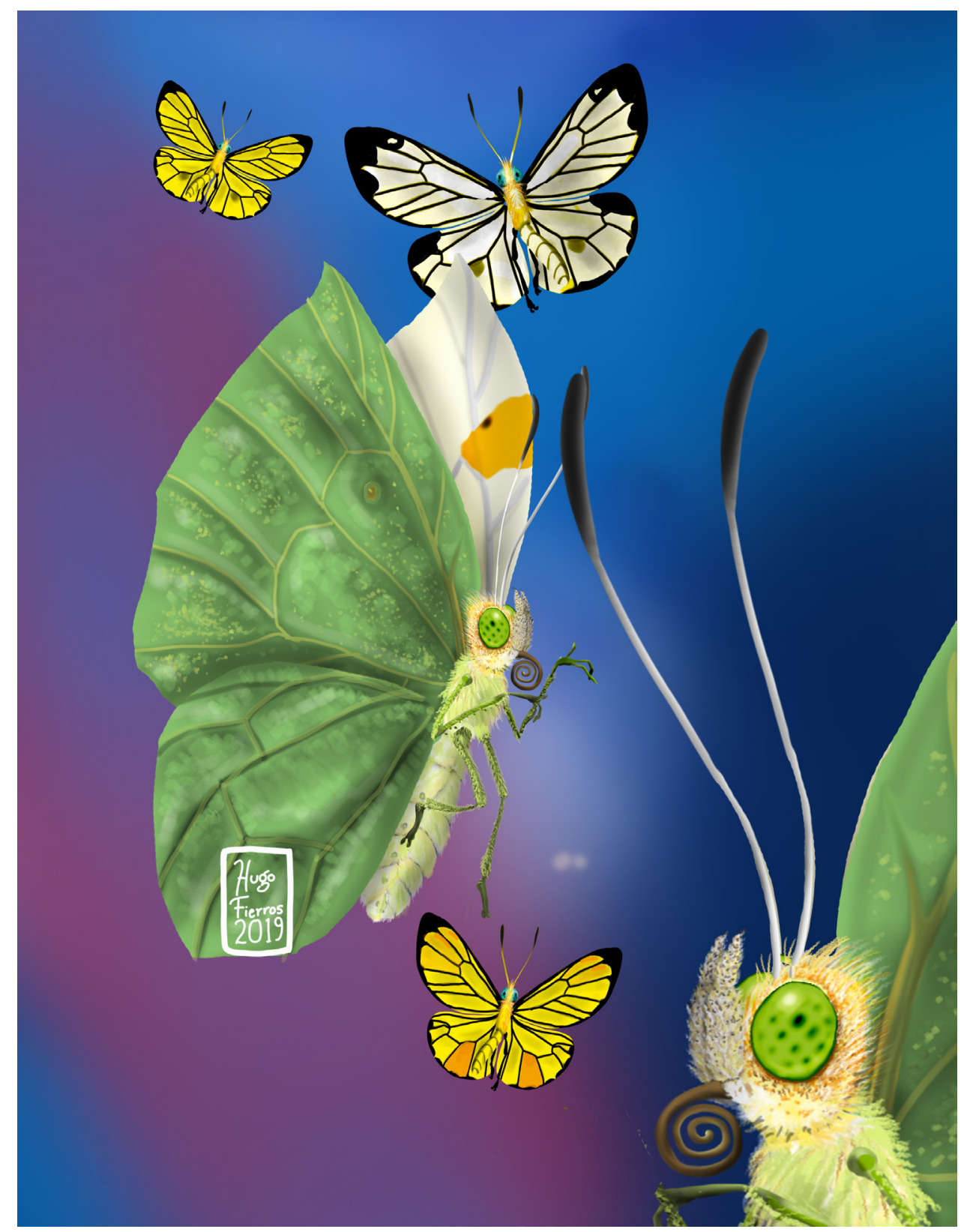

Dugesiana, Año 26, No. 2, julio 2019-diciembre 2019 (segundo semestre de 2019), es una publicación semestral, editada por la Universidad de Guadalajara, a través del Centro de Estudios en Zoología, por el Centro Universitario de Ciencias Biológicas y Agropecuarias. Camino Ramón Padilla Sánchez \# 2100, Nextipac, Zapopan, Jalisco, Tel. 37771150 ext. 33218, http://148.202.248.171/dugesiana/index.php/DUG/index, glenusmx@gmail.com. Editor responsable: José Luis Navarrete Heredia. Reserva de Derechos al Uso Exclusivo 04-2009-062310115100203, ISSN: 2007-9133, otorgados por el Instituto Nacional del Derecho de Autor. Responsable de la última actualización de este número: José Luis Navarrete Heredia, Editor y Ana Laura González-Hernández, Asistente Editorial. Fecha de la última modificación 25 de julio 2019, con un tiraje de un ejemplar.

Las opiniones expresadas por los autores no necesariamente reflejan la postura del editor de la publicación.

Queda estrictamente prohibida la reproducción total o parcial de los contenidos e imágenes de la publicación sin previa autorización de la Universidad de Guadalajara. 


\title{
Llorenteana, a New Butterfly Genus from the American Continent (Lepidoptera: Nymphalidae: Satyrinae)
}

\section{Llorenteana, nuevo género de mariposas del Continente Americano (Lepidoptera: Nymphalidae: Satyrinae)}

\author{
Ángel L. Viloria ${ }^{1 *}$ \& Armando Luis Martínez ${ }^{2}$ \\ ${ }^{1}$ Centro de Ecología, Instituto Venezolano de Investigaciones Cientificas (IVIC), Apartado Postal 20632, Caracas \\ 1020-A, Venezuela.*Correspondence author.email: aviloria@ivic.gob.ve \\ ${ }^{2}$ Museo de Zoología "Alfonso L. Herrera", Departamento de Biología Evolutiva, Facultad de Ciencias, \\ Universidad Nacional Autónoma de México, México 04510 D.F., México.email: alm@ciencias.unam.mx
}

\begin{abstract}
The genus Llorenteana, gen. nov., is diagnosed and described to allocate the enigmatic, relictual, satyrine butterfly, Euptychia pellonia Godman, 1901. The taxonomy of this species had been superficial, variable and unstable for more than a century. The new genus is monobasic and endemic to the montane pine-oak forests of the Northern Mexican Altiplano. Its morphology suggests it should be placed within the Ypthimina Miller, 1968, a subtribe notably diverse in other continents, mainly Africa and Asia, but so far unreported in the American continent.

Keywords: Argestina, Callerebia, Chillanella, Euptychia, Euptychiina, Hemadara, Incertae sedis, Loxerebia, Mashunoides, Megisto, Neosatyrus, Thymipa, Ypthimina, Ypthimomorpha.
\end{abstract}

\section{RESUMEN}

Se diagnostica y describe el género Llorenteana, gen. nov., al cual se asigna la mariposa satírida Euptychia pellonia Godman, 1901, una especie enigmática y relictual. La taxonomía de esta especie había sido superficial, variable e inestable durante más de un siglo. El nuevo género es monobásico y endémico de los bosques de pino-encino del norte del Altiplano Mexicano. Su morfología indica que debería ser ubicado dentro de Ypthimina Miller, 1968, una subtribu notablemente diversa en otros continentes, principalmente África y Asia, pero hasta este momento inadvertida en el continente Americano.

Palabras clave: Argestina, Callerebia, Chillanella, Euptychia, Euptychiina, Hemadara, Incertae sedis, Loxerebia, Mashunoides, Megisto, Neosatyrus, Thymipa, Ypthimina, Ypthimomorpha.

One of the rarest and least known satyrine butterflies from the American continent is the Mexican species Euptychia pellonia Godman, 1901. It was described from a representative series of individuals from montane localities of Durango and Jalisco, and after almost 120 years, few additional specimens have reached entomological collections. The strongly clubbed antennae and the presence of a dorsal, conspicuous, double pupilled subapical ocellus, gives E. pellonia a singular, very unusual aspect, among the members of the American fauna of Satyrinae (especially Neotropical). Its taxonomic position, although only superficially considered in the past, had been so puzzling that it has historically been placed in five different genera: Euptychia Hübner, 1818 (Weymer, 1911; Gaede, 1931; D’Abrera, 1988), Pindis R. Felder, 1869 (Lewis, 1973; L. D. Miller, 1978; Shou et al., 2006), Cissia Doubleday, 1848 (L. D. Miller \& J. Y. Miller, 1988; R. G. De La Maza, 2010), Megisto Hübner, [1819] (R. F. De La Maza \& J. De La Maza, 1987; Llorente Bousquets et al., 1996; Vargas F. et al., 1996; Warren et al., 1996; Luis Martínez et al., 2000; Díaz-Batres et al., 2001; Michán et al., 2004) and Zischkaia Forster, 1964 (Glassberg, 2007). These genera, each notably distinctive, are all allegedly members of the Euptychiina Reuter (1896), a large and widespread, mostly tropical American, subtribe of the Satyrini. Lamas \& Viloria (2004) considered E. pellonia as incertae sedis, but placed it as a member of the Euptychiina.

Close examination of peculiar morphological features of E. pellonia and comparative studies with other species of Satyrinae have shown that it is not closely related to any other representative of the satyrine fauna of America and strongly suggests that it should be placed in its own genus. It is proposed that this new genus belongs in a subtribe, Ypthimina Miller (1968) that has gone so far unnoticed in the American continent.

\section{MATERIALS AND METHODS}

Abbreviations and acronyms: BCA: Biologia Centrali Americana; FWL: Forewing length; HT: Holotype; MZFC: Museo de Zoología "Alfonso Herrera", Facultad de Ciencias, Universidad Nacional Autónoma de México, Ciudad de México; NHMUK: The Natural History Museum, London, UK.

Methods: This is a study of comparative morphology 
of adult butterflies of the subfamily Satyrinae. Type specimens were examined and compared with original descriptions and illustrations for taxonomic identification. We have identified structures, interpreted, compared and described the morphology of wing pattern, wing veins and male genitalia of dry adult butterfly specimens preserved in two major natural history museums. To diagnose and describe the genus herein erected we have also examined the morphology of representatives of almost all genera of Satyrinae recognized in America and a number of externally similar taxa from other continents (mentioned in discussion) and established homological comparisons. Some nomenclatural, taxonomic and biogeographic information has been gathered from published sources (cited in the synonymy, the discussion and the conclusions).

Nomenclatural acts of this work follow the provisions of the International Code of Zoological Nomenclature (International Commission on Zoological Nomenclature, 1999)

Technical procedures: Due to the limited number of specimens examined for this study we have selected the minimum necessary quantity of individuals for dissecting their morphological structures. Wing diaphanization and genitalia dissections were performed by standard basic procedures. These were accomplished by simple chemical treatments like bleaching and, watering of wings and digesting soft abdominal tissues with strong alcaline solutions to remove sclerotized male genitalia structures. Cleaning was performed manually with microdissecting tools under stereoscopic magnification. Illustrations have been produced while examining the insects and their structures with several types and brands of microscopes and stereomicroscopes (Leica, Nikon, Olympus, Wild) coupled with artificial light systems and camera lucida (for drawings) or $35 \mathrm{~mm}$ photographic camera (for macro and microphotographs). Figures were generated with the aid of imaging software Zerene Stacker ${ }^{\mathrm{TM}}$ and Adobe Photoshop ${ }^{\mathrm{TM}}$ (several versions).

\section{RESULTS}

Llorenteana Viloria and Luis-Martínez, gen. nov. http://zoobank.org/E6815CA0-F0C0-4E03-B8F640A735DCAE12

Type species: Euptychia pellonia Godman, 1901: 655, pl. 107, figs. 5, 6; herein designated.

Diagnosis: Members of the new genus Llorenteana, gen. nov., can be diagnosed by their forewing venation, in which the five radials (R1 to R5) conspicuously branch out from a single root or sector; R1 emerging after the first basal sixth of the length of Rs, well beyond the costal corner of the discal cell. This character has only been detected in two other genera of Satyrinae in the American continent: Neosatyrus Wallengren, 1858 and Chillanella Herrera, 1966 (herein considered valid), both restricted to southern latitudes (Chile and Argentina). In all other known American genera forewing R1 always departs independently from the root of R2-R5, at the distal extremity of the discal cell.

Description: Butterflies of small size (males FWL: 17.918.7, $\ddot{\mathrm{x}}=18.5, \mathrm{n}=6$; females FWL: 18.5-20.3, $\ddot{\mathrm{x}}=20.3, \mathrm{n}=5$ ), antennae conspicuously clubbed; forewing subtriangular, with rounded angles; hindwing suboval, outer margins not scalloped. Hindwing lacking ocelli.

Venation (Fig. 2, female): Forewing: Sc independent, inflated at basal third, with small constriction at base, running from base through three fifths of costa; all radials (R1-R5) emerging from same single root, which forms the costal margin of discal cell; R1 branches out towards costa at first sixth of radial sector, beyond distal extremity of discal cell; R2 shorter than other radials, emerging slightly beyond second sixth of radial sector; R3 emerging about half length of radial sector; R4 and R5 diverging at its second third, their distal extremities limiting both sides of wing apex (R4 costal, R5 marginal); M1 independently emerging from anterior extremity of discal cell, running smoothly parallel to radial sector; M2 independent, emerging from distal end of discal cell, more or less half way between emergence of radial sector and that of M3; M3 independent, emerging from the vertex of a right angle formed by the junction of $\mathrm{m}_{2}-\mathrm{m}_{3}$ and $\mathrm{m}_{3}-\mathrm{cu}_{1}$; Cul independent, running free from posterior corner of distal end of discal cell to outer margin, parallel to anal margin; Vogel's chordotonal organ present at base of cubital sector, which is only slightly swollen along its basal third; conspicuous constriction distally limiting Vogel's structure; A2 independently running from wing base to tornus, slightly sinuous and parallel to anal margin; $r_{5}-m_{1}$ straight, one seventh length of $m_{2}-m_{3} ; m_{1}-m_{2}$ curved towards cell, approximately two thirds length of $\mathrm{m}_{2}-\mathrm{m}_{3}$; $\mathrm{m}_{2}-\mathrm{m}_{3}$ straight. Hindwing: Humeral present, thick at base, thin basal branch towards wing base, thick branch, twice as long as previous one emerging towards costa in opposite direction; Sc + R1 ending over middle point of coastal margin; R5 independent, emerging from middle length of anterior border of discal cell, M1, M2 and M3 independent, the latter emerging from distal vertex of discal cell, ending in middle point of outer margin; $\mathrm{Cu} 1$ and $\mathrm{Cu} 2$ independent and more or less straight; $\mathrm{A} 2$ and $\mathrm{A} 3$ both independent but emerging from wing base very close to each other, quickly diverging as they run separately; A2 ends at tornus; A3 ends at first, basal third of anal margin; $r s-m_{1}$ straight; $m_{1}-m_{2}$ double length of rs- $\mathrm{m}_{1}$, slightly angled towards cell; $\mathrm{m}_{2}-\mathrm{m}_{3}$ straight, twice length of $\mathrm{m}_{1}-\mathrm{m}_{2}$.

Wing pattern (Fig. 1, male): prominent black postdiscal ocellus on forewing (recto and verso), in middle of cell M1, central pupil white; smaller element from neighboring cell M2 expressed as fused satellite of main M2, with a second, excentric, white pupil.

Male genitalia (Fig. 3): genital capsule compact and stout, thickly sclerotized (3A, B, C). Tegumen subglobular, not much higher than the origin of uncus; the latter more or less distinct from tegumen, beak-like,1.3 times as long as tegumen, slightly curved, pointing downwards; subunci stylized and well defined, thin but stout, half length of uncus, 

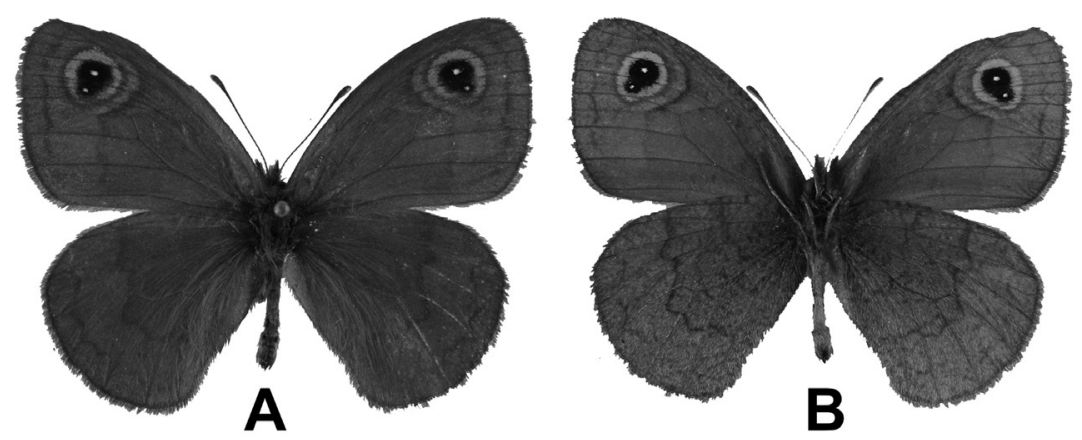

Figs. 1. Habitus of Llorenteana pellonia (Godman, 1901), comb. nov., male (MZFC 66965). A. Dorsal; B. Ventral.

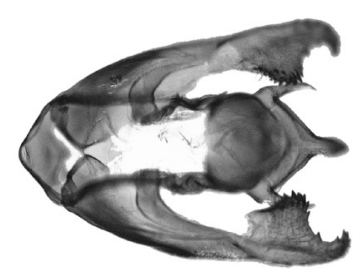

A

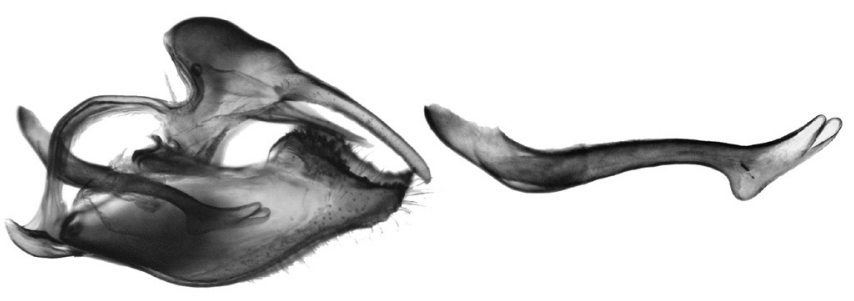

C

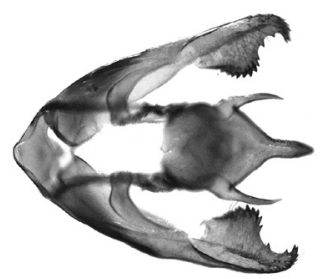

B

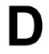

Fig. 3. Male (MZFC 66965) genitalia of Llorenteana pellonia (Godman, 1901), comb. nov., A. Dorsal view of the genital capsule, aedeagus removed; B. ventral view of the genital capsule, aedeagus removed; $\mathbf{C}$. Lateral view of the genital capsule, with aedeagus in natural position; D. Lateral view of detached aedeagus.

emerging laterally outwards, just below base of uncus; vinculum thin, stout, strongly sigmoidal in lateral view, forming a ring laterally compressed; saccus as wide as tegumen and very short, dorsally depressed; valvae moderately setose at distal quarter, large, deep in lateral view, broader at base, as much as lateral extension of tegumen, slightly less towards tip, ampullar process conspicuous with many short, denticular spines pointing to inner side, distal spiny process; a diastema or space without spines between ampulla and distal tip; aedeagus (Fig. $3 \mathrm{D})$ very strong and rather sclerotized, moderately thick, sinuous in lateral view, a broad, bifid distal extremity, reminiscent of a human foot in lateral view.

Material examined: MEXICO, Jalisco: 1 male (Type HT), Bolaños, Jalisco, Mex.[ico], Richardson, Godman-Salvin Coll.1904-1., B. C. A. Lep. Rhop. Euptychia pellonia, Godm., Agrees with Figure of Type. N.[orman] D. R.[iley], B. M. TYPE No. Rh. 3295, Euptychia pellonia, [male] Godm., SYNTYPE Euptychia pellonia Godman \& Salvin, det. P. Ackery 1974 [NHMUK]; Durango:

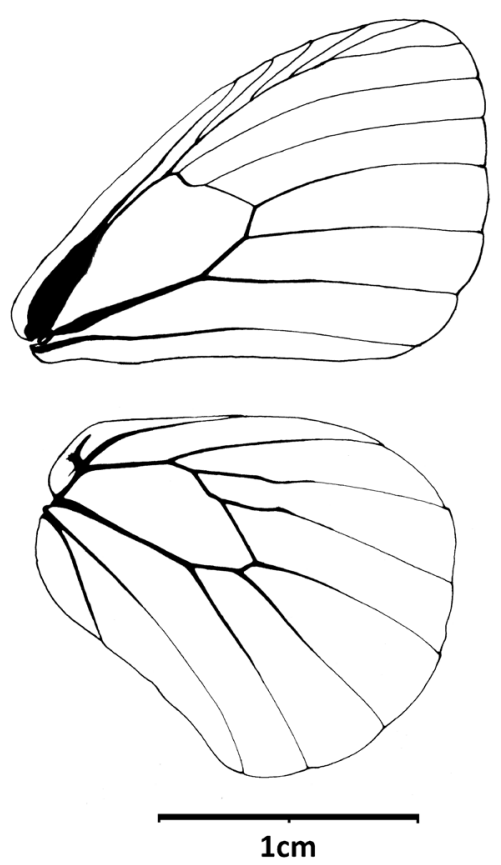

Fig. 2. Wing venation of Llorenteana pellonia (Godman, 1901), comb. nov., female (MZFC 56108).

1 male (MZFC 56097), 1 female (MZFC 56096), $25 \mathrm{mi} \mathrm{W}$ Durango, 2401'18',-105'03'11', 20.vii.1964, J. A. Powell; 1 female (MZFC 56126, Genit. prep. ALV-528-14, 11.xii.2014), $29 \mathrm{mi}$ W Durango, $28^{\circ}$ 08'25",-104' 58'23", 20.vii.1964, J. A. Powell; 1 male (MZFC 56125), $30 \mathrm{mi}$ W Durango, $24^{\circ} 01^{\prime} 18^{\prime \prime},-105^{\circ}$ 05'17', 31.vii.1964, J. A. Powell; 1 male (MZFC 56098), 1 female (MZFC 56099), $29 \mathrm{mi} \mathrm{W}$ Durango, 240' $25^{\prime}$ ", -104 58'23”, 18.vii.1969, J. A. Powell; 1 male (MZFC 56107), 1 female (MZFC 56108, Wing prep. ALV009-14, Genit. prep. ALV527-14, 11.xii.2014), same data, 7.viii.1972; 2 males (MZFC 66723, 66965 [Fig. 1 A (dorsal), B (ventral)]), 1 female (MZFC 66964), La Michilía, Mesa del Burro, Municipio Súchil, [Durango], $23^{\circ} 35^{\prime} 17^{\prime \prime}$, -104 04'33", 3.viii.1984,

\section{E. Díaz B. [MZFC]}

Etymology: Llorenteana means "belonging or relative to Llorente". It is a feminine Spanish derivation of the first surname of our long-time friend and colleague, Jorge Enrique Llorente Bousquets, prominent Mexican scientist, philosopher, evolutionary biologist, biogeographer 
and especially, lepidopterist. He is an Emeritus Professor of the Universidad Nacional Autónoma de México (UNAM). Professor Llorente Bousquets owns a rich academic record among Latin American lepidopterists. He was one of the founders of the Museo de Zoología "Alfonso L. Herrera" in the Faculty of Sciences at UNAM, where he pioneered and continues developing modern studies of systematics, faunistics and biogeography of Mexican and other Neotropical butterflies. Our knowledge of the butterfly fauna of Mexico has been greatly improved by the initiative and persisting efforts of Jorge Llorente and the members of his research team, as to become one of the most complete of any country in Latin America. We feel honored to name this new, peculiar genus of satyrine butterfly endemic to Mexico after Jorge Llorente, tutor, companion and mentor.

Llorenteana, gen. nov., is herein recognized as a monobasic genus of satyrine butterflies, endemic to the mountains of the northern Mexican Altiplano.

Llorenteana pellonia (Godman, 1901), comb. nov.

Figs. 1 male, A (dorsal), B (ventral);

2 female (wing venation); 3 male (A-D genitalia)

Euptychia pellonia Godman, 1901: ii, xxxii, 655, pl. 107, figs. 5,6 .

Euptychia pellonia Godman; Weymer, 1911: 202; Gaede, 1931: 459; D’Abrera, 1988: 876 [index].

Pindis pellonia (Godman); Lewis, 1973: 235, pl. 63, fig. 16; L. D. Miller, 1978: 1; Shou et al., 2006: 86.

"Euptychia" pellonia Godman \& Salvin [sic]; L. D. Miller, 1978: 1 .

'?' pellonia Cramer [sic]; D'Abrera, 1988: 788, 789 [rows 4, 5] figs. male recto, verso.

Cissia pellonia (Godman \& Salvin) [sic]; L. D. Miller \& J. Y. Miller, 1988: 276; R. G. De La Maza, 2010: 184.

Megisto pellonia (Godman); R. F. De La Maza \& J. De La Maza, 1987: 94, 200 lám. 24, fig. 10; Llorente Bousquets et al., 1996: 45; Vargas F. et al., 1996:128; Warren et al., 1996: 15; Luis Martínez et al., 2000: 285; Díaz Batres et al., 2001: 41

"Megisto" pellonia (Godman); Michán et al., 2004: 40; 2005: 130.

[Incertae sedis] pellonia Godman; Lamas \& Viloria, 2004: 223.

Zischkaia pellonia (Godman); Glassberg, 2007: 139 figs.

\section{DISCUSSION}

Diagnostic or prominent characters of Llorenteana, gen. nov., could only be compared with those of a limited number of satyrine taxa. In the American continent, forewing radial veins all emerging from a single root is a character so far detected in two austral genera of the Andean region: Neosatyrus Wallengren (1858) and Chillanella Herrera (1966) (Wallengren, 1858: 79; Hayward, 1958: 258-259; Herrera, 1966: 71; Herrera \& Howarth, 1966: 121, fig. 77, 122, fig. 83). It is found in some African genera such as Thymipa Moore (1893), Ypthimomorpha Van Son (1955: 152, fig. 175c) and Mashunoides Mendes \& Bivar de Sousa (2009: 8, fig. 1), along with some Asian species currently classified in the genus Ypthima Hübner, 1818, which are certainly not close to the type species of the genus, $Y$. huebneri Kirby, 1871: 'Ypthima' philomela (Linnaeus, 1763), 'Ypthima' coorgensis Sharma, 2013 and 'Ypthima' tripuraensis Sharma, 2013. Members of the Y. huebneri group have a different arrangement in the forewing radial veins and have been set apart, as supported by molecular phylogenies (see Sharma, 2013: 8 fig.1, 9 fig. 11; JismingSee et al., 2016; Osozawa et al., 2017).

Among American satyrs, the double-pupilled postdicalsubapical ocellus on the forewing upperside is only found in some species placed in the southern South American genera Pampasatyrus Hayward (1953) and Stegosatyrus Zacca, Mielke \& Pyrcz (2013), the North American genus Megisto and the enigmatic species 'Euptychia' rubricata W. H. Edwards, 1871, recently classified in Cissia by Zacca et al. (2018). However, it is a generalized trait within the Asian and African ypthimine satyrids.

The markedly capsular male genitalia of Llorenteana, gen. nov., is only comparable to similarly featured structures in a few genera of American Satyrinae, including the Mexican-North American Paramacera Butler, 1868 and Gyrocheilus Butler, 1867, the Central American and West Colombian Inbio Nakahara \& Espeland, 2015, and the West Indian Calisto Hübner, 1823. Subtribal allocation of all these genera is currently uncertain.

Certain Asian genera of Satyrinae contain species that can be superficially similar to Llorenteana pellonia, comb. nov., but they do not share the diagnostic character of $\mathrm{R} 1$ emerging distad to the discal cell in the forewing. Such is the case of Argestina Riley (1923: 469). The morphology of the genitalia in males of the genera Callerebia Butler (1867), Hemadara Moore (1893) and Loxerebia Watkins (1925), may be reminiscent of that of Llorenteana gen. nov., particularly in the general shape of the valvae or the reduced saccus. However, they lack the characteristic sigmoidal vinculum of the new Mexican genus (see Della Bruna et al., 2002; Huang \& Wu, 2003; Singh, 2015).

\section{CONCLUSIONS}

Judging from the aforementioned morphological homologies, especially wing venation, but also wing pattern affinities, Llorenteana pellonia (Godman), comb. nov., should be considered a member of the subtribe Ypthimina Miller (1968). It represents the first and so far only confirmed example of this clade known in the American continent; a possible relictual element confined to particular montane forest habitats of the northern Mexican Altiplano, chiefly "bosque de pino - encino", but also "matorral" and "bosque de pino - encino -madroño" (Díaz Batres et al., 2001). Comparative genetic studies (DNA sequencing and molecular phylogenies) are needed to test this hypothesis. Paralleling the case of close relationship between the North American Megisto Hübner and the Asian Palaeonympha Butler (Peña et al., 2010), which cannot be taken as an isolated biogeogaphic anomaly, we would expect the nearest relative of Llorenteana, gen. nov., to be found among the rich ypthimine fauna of central or eastern Asia. 


\section{ACKNOWLEDGEMENTS}

Short visits and longer working periods by ALV at the NHMUK were funded by La Universidad del Zulia, CONICIT and The British Council (1995-1998), Instituto Venezolano de Investigaciones Científicas (IVIC) (2001, 2003), Programa Antártico Venezolano (2010), Vicepresidencia de la República Bolivariana de Venezuela (2011), Fujian Agriculture and Forestry University (Fuzhou, China) and Embajada de la República Bolivariana de Venezuela en Polonia (2016). Research activities in the NHMUK were greatly facilitated by the assistance of P. R. Ackery, B. $(\dagger)$ and L. D’Abrera, B. Huertas, D. C. Lees, A. F. E. Neild, J. Reynolds, and R. I. Vane-Wright, of the former Department of Entomology, now Insects Division of the Life Sciences Department. Financial and logistic support for ALV travels to Mexico and research work in the MZFC (2015) came from the Universidad Nacional Autónoma de México through the efforts of Professor Jorge Llorente Bousquets and his research team. For developing this and other connected works, ALV received hospitality from G. Beccaloni, B. Huertas and T. Donegan, and A. F. E. Neild (London), and J. Llorente Bousquets and J. Castro (Mexico). The authors thank I. Vargas Fernández, A. Arellano, M. Trujano, J. L. Salinas and D. J. Castro for their assistance in several steps of the preparation of this article. Thanks to the projects DGAPA PAPIIT IN212418 and CONACyT 284966 A. D. Warren and an anonymous reviewer added information, detected several errors and inconsistencies in the first version of this article and helped to improve its quality. Their contribution is deeply acknowledged.

\section{LITERATURE CITED}

Butler, A. G. 1867. Descriptions of some remarkable new species and a new genus of diurnal Lepidoptera. Annals and Magazine of Natural History, (3)20(117): 216-217, pl. 4.

D'Abrera, B. 1988. Butterflies of the Neotropical Region. Part V. Nymphalidae (Conc.) \& Satyridae. Hill House, Victoria, Black Rock.

De La Maza, R. F. \& J. De La Maza. 1987. Mariposas mexicanas. Guía para su colecta y determinación. Fondo de Cultura Económica, México, D. F.

De La Maza, R. G. 2010. Lepidópteros diurnos. (pp. 179-194). In: Ceballos, G., L. Martínez, A. García, E. Espinoza, J. Bezaury and R. Dirzo (Eds.). Diversidad, amenazas y áreas prioritarias para la conservación de las selvas secas del Pacífico de México. Fondo de Cultura Económica. México, D. F.

Della Bruna, C.; E. Gallo; M. Lucarelli and V. Sbordoni. 2002. Guide to the butterflies of the Palaearctic Region: Satyrinae II. Tribe Satyrini. $2^{\text {nd }}$ ed. Omnes Artes, Milano.

Díaz-Batres, M. E., J. Llorente Bousquets, I. Vargas Fernández and A. Luis Martínez. 2001. Papilionoidea (Lepidoptera) de la Reserva de la Biosfera La Michilía en Durango, México (pp. 35-56). In: Vargas, M.,
O. J. Polaco and G. Zúñiga (Eds.). Contribuciones entomológicas. Homenaje a la Dra. Isabel Bassols Batalla. Instituto Politécnico Nacional, Escuela Nacional de Ciencias Biológicas, México, D. F.

Gaede, M. 1931. Familia Satyridae. Lepidopterorum Catalogus, 43: 1-320; 46: 321-544; 48: 545-759.

Glassberg, J. 2007. A swift guide to the butterflies of Mexico and Central America. Sunstreak Books, Inc., Morristown.

Godman, F. Du C. 1901. Biologia Centrali-Americana. Insecta. Lepidoptera-Rhopalocera. Dulau \& Co., Bernard Quaritch, London, 1(168): i-xlvi; (164): 645668, pls. 104-105; (165): 669-692, pls. 106-107.

Hayward, K. J. 1953. Satíridos argentinos (Lep. Rhop. Satyridae) I. Los géneros (excluídos Euptychia y Neomaniola). Acta Zoologica Lilloana, 13: 5-66.

Hayward, K. J. 1958. Satíridos argentinos (Lep. Rhop. Satyridae) III. Guía para su clasificación. Acta Zoológica Lilloana, 15: 199-296, 8 pls.

Herrera, J. 1966. Quilaphoetosus, Chillanella y Haywardella nuevos géneros de Satyridae andinos (Lepidoptera). Publicaciones del Centro de Estudios Entomológicos. Universidad de Chile, 8: 69-72.

Herrera, J. and T. G. Howarth. 1966. Genitalia de los tipos de Satyridae de Chile depositados en el British Museum. Publicaciones del Centro de Estudios Entomológicos. Universidad de Chile, 8: 73-126.

Huang, H. and C.-S. Wu. 2003. New and little known Chinese butterflies in the collection of the Institute of Zoology, Academia Sinica, Beijing-1 (Lepidoptera: Rhopalocera). Neue Entomologische Nachrichten, 55: 115-143.

International Commission on Zoological Nomenclature. 1999. International Code of Zoological Nomenclature / Code International de Nomenclature Zoologique. $4^{\text {th }}$ ed. The International Trust for Zoological Nomenclature, London.

Jisming-See, S.-W., K.-W. Sing and J.-J. Wilson. 2016. DNA barcodes and citizen science provoke a diversity reappraisal for the "ring" butterflies of Peninsular Malaysia (Ypthima: Satyrinae: Nymphalidae: Lepidoptera). Genome, 59(10): 879-888.

Lamas, G. and Á. L. Viloria. 2004. Nymphalidae. Satyrinae. Tribe Satyrini. Subtribe incertae sedis. (pp. 224). In: Lamas, G. (Ed.). Checklist: Part 4A. Hesperioidea - Papilionoidea. In: Heppner, J. B. (Ed.). Atlas of Neotropical Lepidoptera. Volume 5A. Association for Tropical Lepidoptera; Scientific Publishers, Gainesville. Lewis, H. L. 1973. Butterflies of the World. Follett, Chicago. Llorente Bousquets, J., A. Luis Martínez, I. Vargas Fernández and A. D. Warren. 1996. Lista de las mariposas del Estado de Jalisco, México. Revista de la Sociedad Mexicana de Historia Natural, 46: 35-48.

Luis Martínez, A., J. Llorente Bousquets, I. Vargas Fernández and A. L. Gutiérrez. 2000. Síntesis preliminar del conocimiento de los Papilionoidea (Lepidoptera: 
Insecta) de México. (pp. 275-285). In: Martín-Piera, F., J. J. Morrone and A. Melic (Eds.). Hacia un Proyecto CYTED para el Inventario y Estimación de la Diversidad Entomológica en Iberoamérica: PrIBES 2000. Sociedad Entomológica Aragonesa, Zaragoza.

Mendes, L. F. and A. Bivar de Sousa. 2009. On a new South-Eastern Angolan satyrine butterfly belonging to a new genus (Lepidoptera: Nymphalidae). Entomologia Africana, 14(2): 5-9.

Michán, L., J. Llorente Bousquets, A. Luis Martínez and D. J. Castro. 2004. Breve historia de la taxonomía de Lepidoptera en México durante el siglo XX. (pp. 5-42). In: Llorente Bousquets, J. E., J. J. Morrone, O. Yáñez Ordóñez and I. Vargas Fernández (Eds.). Biodiversidad, Taxonomía y Biogeografía de Artrópodos de México: Hacia una síntesis de su conocimiento. Volumen IV. Universidad Nacional Autónoma de México, México, D. F.

Michán, L., J. Llorente Bousquets, A. Luis Martínez and D. J. Castro. 2005. Breve historia de la taxonomía de Lepidoptera en México durante el siglo XX. Revista de la Academia Colombiana de Ciencias, 29(110): 101132.

Miller, L. D. 1968. The higher classification, phylogeny and zoogeography of the Satyridae (Lepidoptera). Memoirs of the American Entomological Society, 24: [6] + iii + $174 \mathrm{pp}$.

Miller, L. D. 1978. Revision of the Euptychiini (Satyridae). 4. Pindis R. Felder. Bulletin of the Allyn Museum, 50: $1-12$.

Miller, L. D. and J. Y. Miller. 1988. A new Euptychia species from northwestern Mexico (Satyridae). Journal of the Lepidopterists' Society, 42(4): 276-280.

Moore, F. 1893. Lepidoptera Indica. Volume 2. Parts XIII$X V I I$. L. Reeve \& Co., London.

Osozawa, S., M. Takahashi and J. Wakabayashi. 2017. Quaternary vicariance of Ypthima butterflies (Lepidoptera Nymphalidae, Satyrinae) and systematics in the Ryukyu Islands and Oriental Region. Zoological Journal of the Linnean Society, 180(3): 593-602.

Peña, C., S. Nylin, A.V.L. Freitas and N. Wahlberg. 2010. Biogeographic history of the butterfly subtribe Euptychiina (Lepidoptera, Nymphalidae, Satyrinae). Zoologica Scripta, 39(3): 243-258.

Recibido: 7 de junio 2019

Aceptado: 1 de julio 2019
Reuter, E. 1896. Über die Palpen der Rhopalocera. Ein Beitrag zur Erkenntnis der verwandtschaftlichen Beziehungen unter den Tagfaltern. Acta Societatis Scientiarum Fennicae, 22(1): i-xvi, 1-577, 6 pls.

Riley, N. D. 1923. The Rhopalocera of the Mt. Everest 1921 Expedition. Transactions of the Entomological Society of London, 1922(3/4): 461-482, pls. 36-37.

Sharma, N. 2013. Two new species of the genus Ypthima Hübner (Lepidoptera: Papilionoidea: Satyridae) from India and Myanmar. Records of the Zoological Survey of India, 113(3): 1-10.

Shou, J., I. Chou and Y. Li. 2006. Systematic butterfly names of the world. Shaanxi Science and Technology Press, Xian.

Singh, A. P. 2015. On the female morphs, ecology and male genitalia of Callerebia dibangensis Roy (Lepidoptera: Nymphalidae: Satyrinae) recorded near Mayodia Pass in lower Dibang Valley, Arunachal Pradesh, India. Journal of Threatened Taxa, 7(5): 7168-7174.

Van Son, G. 1955. The butterflies of Southern Africa. Part II. Nymphalidae: Danainae and Satyrinae. Transvaal Museum, Pretoria.

Vargas F., I., A. Luis M., J. Llorente B. and A. D.Warren. 1996. Butterflies of the State of Jalisco, Mexico. Journal of the Lepidopterists'Society, 50(2): 97-138.

Wallengren, H.1858. Nya Fjäril-slägten. Nova Genera Lepidopterorum. Öfversigt af Kongliga VetenskapsAkademiens Förhandlingar, 15(2): 75-84.

Warren, A. D., I. Vargas Fernández, A. Luis Martínez and J. Llorente Bousquets. 1996. Mariposas diurnas de Jalisco. Dugesiana, 3(1): 1-20.

Watkins, H. T. G. 1925. New Callerebias (Lepidoptera: Satyridae). Annals and Magazine of Natural History, (9)16(92): 233-237.

Weymer, G. 1911. 4. Familie: Satyridae. (pp. 193-240, pl. 47). In: Seitz, A. (Ed.). Die Gross-Schmetterlinge der Erde, 5. A. Kernen, Stuttgart.

Zacca, T., M. M. Casagrande, O. H. H. Mielke, B. Huertas, E. P. Barbosa, A. V. L. Freitas, L. M. Magaldi, M. Espeland, S. Nakahara and K. R. Willmott. 2018. Systematics of the butterfly genus Cissia Doubleday, 1848 (Lepidoptera: Nymphalidae: Satyrinae) using an integrative approach. Arthropod Systematics and Phylogeny, 76(2): 349-376.

Zacca, T., O. H. H. Mielke, T. W. Pyrcz, M. M. Casagrande, A. V. L. Freitas and P. Boyer. 2013. Stegosatyrus, a new genus of Euptychiina from the grasslands of Neotropical realm (Lepidoptera: Nymphalidae: Satyrinae). Zootaxa, 3682(2): 331-350. 